\title{
Invited review: Effect, persistence, and virulence of coagulase-negative Staphylococcus species associated with ruminant udder health
}

\author{
W. Vanderhaeghen, ${ }^{*}$ S. Piepers, ${ }^{*}$ F. Leroy,† E. Van Coillie,‡ F. Haesebrouck,§ and S. De Vliegher ${ }^{* 1}$ \\ *M-Team \& Mastitis and Milk Quality Research Unit, Department of Reproduction, Obstetrics and Herd Health, Faculty of Veterinary Medicine, \\ Ghent University, Salisburylaan 133, 9820 Merelbeke, Belgium \\ †Research Group of Industrial Microbiology and Food Biotechnology, Faculty of Sciences and Bioengineering Sciences, Vrije Universiteit Brussel, \\ Pleinlaan 2, 1050 Brussels, Belgium \\ $\ddagger$ Technology and Food Science Unit, Institute for Agricultural and Fisheries Research (ILVO), Brusselsesteenweg 370, 9090 Melle, Belgium \\ $\S$ Department of Pathology, Bacteriology and Avian Diseases, Faculty of Veterinary Medicine, Ghent University, Salisburylaan 133, \\ 9820 Merelbeke, Belgium
}

\begin{abstract}
The aim of this review is to assess the effect of coagulase-negative staphylococci (CNS) species on udder health and milk yield in ruminants, and to evaluate the capacity of CNS to cause persistent intramammary infections (IMI). Furthermore, the literature on factors suspected of playing a role in the pathogenicity of IMIassociated CNS, such as biofilm formation and the presence of various putative virulence genes, is discussed. The focus is on the 5 CNS species that have been most frequently identified as causing bovine IMI using reliable molecular identification methods (Staphylococcus chromogenes, Staphylococcus simulans, Staphylococcus haemolyticus, Staphylococcus xylosus, and Staphylococcus epidermidis). Although the effect on somatic cell count and milk production is accepted to be generally limited or nonexistent for CNS as a group, indications are that the typical effects differ between CNS species and perhaps even strains. It has also become clear that many CNS species can cause persistent IMI, contrary to what has long been believed. However, this trait appears to be quite complicated, being partly strain dependent and partly dependent on the host's immunity. Consistent definitions of persistence and more uniform methods for testing this phenomenon will benefit future research. The factors explaining the anticipated differences in pathogenic behavior appear to be more difficult to evaluate. Biofilm formation and the presence of various staphylococcal virulence factors do not seem to (directly) influence the effect of CNS on IMI but the available information is indirect or insufficient to draw consistent conclusions. Future studies on the effect, persistence, and virulence of the different CNS species associated with IMI would benefit from using
\end{abstract}

Received November 27, 2013.

Accepted May 12, 2014.

${ }^{1}$ Corresponding author: Sarne.Devliegher@UGent.be larger and perhaps even shared strain collections and from adjusting study designs to a common framework, as the large variation currently existing therein is a major problem. Also within-species variation should be investigated.

Key words: coagulase-negative staphylococci (CNS), intramammary infection, effect, persistence, biofilm, virulence

\section{CNS AND UDDER HEALTH}

\section{Mastitis and CNS}

Mastitis is an inflammation of the mammary gland that commonly originates from IMI, most often caused by bacteria such as streptococci, coliforms, and staphylococci. The disease appears in 2 forms: either clinical, characterized by visible symptoms, sometimes general illness, and a long lasting negative effect on milk production, or subclinical, without visible symptoms but with an increase in SCC and suboptimal milk production. In the last decade, the CNS have become the microorganisms most frequently identified in cases of subclinical mastitis, arousing enhanced interest from mastitis researchers (Pyörälä and Taponen, 2009; De Vliegher et al., 2012).

Coagulase-negative staphylococci, along with other agents such as Corynebacterium spp., are commonly considered to be minor mastitis pathogens, as opposed to major pathogens such as Staphylococcus aureus, Escherichia coli, Streptococcus uberis, and Streptococcus agalactiae. However, conflicting results on aspects such as the effect of CNS IMI on SCC and milk yield (MY), and the virulence potential and epidemiology of CNS found in milk, have caused confusion regarding the true importance of CNS for udder health. This confusion has led researchers to challenge the idea that CNS are a homogeneous bacterial group. Instead, the existence of species-specific differences has been predicted (Pyörälä and Taponen, 2009). Several recent studies, outlined 
below, have focused on the diversity among CNS species with respect to their role in ruminant udder health.

\section{Main CNS Found in Ruminant Milk}

A major drawback for looking beyond the border of CNS as a group has long been the lack of consistent identification and typing methods for isolates from nonhuman sources. Indeed, the routine phenotypic methods that were traditionally used to identify CNS species from milk were essentially developed for use with human isolates and were proven unreliable in case of (some) CNS species found in milk (Thorberg and Brändström, 2000; Taponen et al., 2006, 2008; Capurro et al., 2009; Sampimon et al., 2009b; Onni et al., 2010, 2012; Park et al., 2011a; Koop et al., 2012a). Recent studies have been able to overcome these difficulties as various validated molecular methods, including sequencing and fingerprinting methods, have become available (Piessens et al., 2010; Braem et al., 2011). If one now looks at studies presenting reliable species data, over 20 CNS species have so far been isolated from bovine milk (Taponen et al., 2007; Sampimon et al., 2009b; Park et al., 2011a; Persson Waller et al., 2011; Piessens et al., 2011; Supré et al., 2011; Mørk et al., 2012; Quirk et al., 2012). However, overall, just 5 species are commonly found: Staphylococcus chromogenes, being generally the most frequently detected species, Staphylococcus simulans, Staphylococcus xylosus, Staphylococcus haemolyticus, and Staphylococcus epidermidis. Therefore, the rest of this review will focus mainly on these species, which will further be referred to as the 5 main species. Sometimes other CNS species from milk will be considered in addition to the 5 main species, such as Staphylococcus caprae, being one of the main species in milk from goats and sheep (Onni et al., 2010, 2012; Koop et al., 2012a), as will CNS species from other niches than milk, including humans or the bovine environment. Studies with species data resulting from (solely) phenotypic identification will occasionally be cited.

\section{Determining Udder Health Status}

Udder health can be expressed in various ways. First, the inflammatory response of the cow can be determined, which is most frequently done, both in practice and in research, through measuring the SCC. Other parameters such as $N$-acetyl- $\beta$-glucosaminidase (NAGase), milk amyloid A (MAA) level, serum amyloid A (SAA) level, and the level of proinflammatory cytokines interleukin or tumor necrosis factors have been considered (Simojoki et al., 2011; Kalmus et al., 2013). Second, the detection of visible signs, such as swelling, redness, and hardness of the udder, represents an obvious, macroscopic way to assess udder health. Interestingly, a significant positive association has recently been illustrated for the severity of the clinical signs with inflammatory markers in the milk (Kalmus et al., 2013). A third parameter, possibly the most appreciable for the farmer, is milk production, indirectly related to udder health and several other disorders of infectious or metabolic origin. These 3 aspects are all expressions of an inflammatory or other physical reaction of the host and, in this review, the effect of CNS will be discussed in relation to all 3 . In addition, in some studies, only the presence, absence, or new occurrence of IMI is determined, without taking any reaction of the host in consideration. Also this approach to udder health will be discussed.

\section{Persistence of IMI}

Persistent IMI is viewed as a major issue related to staphylococcal mastitis. It refers to the occurrence of the same infectious agent in the milk throughout a certain period, such as the dry period or part of or even the entire lactation. However, assessing persistence of IMI especially requires consistent strain identification. Although persistence of an infectious agent can be suspected when the same species is detected in consecutive samples (Taponen et al., 2006; Supré et al., 2011; Koop et al., 2012b), reliable conclusions can only be made when appropriate typing methods have shown these samples to harbor identical strains (Rajala-Schultz et al., 2009). Concerning staphylococci, recent research has shown that when an udder quarter yields a series of samples positive for a certain Staphylococcus species over time, it is likely to be persistently infected (Mørk et al., 2012). Therefore, molecular studies only including species data can be argued to yield valuable insights on the persistence capacities of CNS, even though they are not conclusive.

\section{Biofilm Formation and Other Putative Virulence Factors of Staphylococci}

In general, 3 groups of virulence factors are involved in pathogenesis of staphylococcal infections: secreted proteins (e.g., superantigens, cytotoxins, and tissuedegrading enzymes), cell surface-bound proteins [e.g., microbial surface components recognizing adhesive matrix molecules (MSCRAMM)], and cell wall components (e.g., the polysaccharide capsule and lipoteichoic acid; Arvidson, 2006; Dedent et al., 2006; Novick, 2006; Atanasova et al., 2011). Besides their cytological origin, virulence factors can also be considered according to their role during pathogenesis [i.e., in adhesion to the host tissue (e.g., MSCRAMM, such as fibrinogen-binding protein and fibronectin-binding protein), in evasion 
or inhibition of the host's defense mechanisms (e.g., staphylokinase, hemolysins, leukotoxins, and superantigen-like proteins), or in degradation of host tissue (e.g., proteases, lipases, hyaluronidases, collagenases, and iron-sequestering proteins)]. A special class are the superantigens (e.g., enterotoxins, exfoliative toxins, and toxic shock syndrome toxin-1), which may have several functions, including immunosuppression (Ferens et al., 1998; Seo et al., 2007). They have the ability to induce nonspecific T-cell proliferation, which may result in a massive systemic cytokine release, leading to severe or life-threatening conditions. Below, the presence and importance of (variants of) these factors in CNS isolated from milk will be discussed.

It is currently accepted, in human medicine, that probably the most important virulence factor of CNS is biofilm formation, which fulfills a role in adhesion as well as in the evasion of the host's defense mechanisms (Otto, 2013). Biofilm formation is an excellent method to promote and sustain bacterial presence at or beyond an (inflicted) host site, likely presenting an advantage for CNS to gain and maintain their presence on external and internal udder tissue. Accordingly, biofilm formation has been suggested to be an important factor involved in the establishment and maintenance of CNS causing IMI (Clutterbuck et al., 2007). This will be further addressed below.

Biofilm production can be tested phenotypically, through investigation of the growth of bacteria onto a surface or their ability to form an extracellular polysaccharide matrix, for which different in vitro techniques have been developed (Christensen et al., 1985; Freeman et al., 1989; Oliveira et al., 2006). In addition, genotypic approaches can be used, as a variety of genes involved in biofilm formation have been identified in staphylococci. The earliest recognized genetic underpinning has been associated with the icaADBC operon, encoding the polysaccharide intercellular adhesin, also known as polymeric $N$-acetyl-glucosamine (PNAG; Heilmann et al., 1996; Mack et al., 1996). Other examples are aap, encoding the accumulation-associated protein (Rohde et al., 2005); bap, encoding the biofilm-associated protein (Cucarella et al., 2001); embp, encoding the extracellular matrix binding protein (Christner et al., 2010); spa, encoding protein A (Merino et al., 2009); fnbA and $f n b B$, encoding fibrinogen-binding proteins $\mathrm{A}$ and B, respectively (O'Neill et al., 2008); sasG, encoding Staph. aureus surface protein G (Corrigan et al., 2007); atlE, encoding the bifunctional adhesin and autolysin AtlE (Heilmann et al., 1996); and still some others (Otto, 2013). The presence of (some of) these genes and the capacity to produce biofilm in CNS species isolated from milk as well as any species-specific differences in these traits will be discussed below.

\section{Methodological Considerations}

In general, assessment of the available studies on CNS and udder health is complicated by several confounding factors. A first problem is the large variation in the numbers of isolates available for each reported CNS species in different studies, sometimes leading to low discriminatory power and compromising species comparisons within and between studies. Each study was, therefore, assessed individually, and only those species found in the highest numbers were deemed relevant to draw conclusions on. A second problem is related to the fact that the declared origin of CNS isolates can be problematic to interpret, as origin labels such as "found in milk," "causing IMI," and "present in cases of mastitis" are not always sharply delineated between studies. In this concern, it must be noted that in studies referring to "milk samples" as the origin of isolates, evidently the intramammary tissue is (mostly) meant as the actual origin of the isolates. We trust the reader to be well aware of this, as in the further text we also refer to "milk samples" and "isolates from milk," being the most objective representation of the facts. A third problem is that available studies may differ considerably in their definition of persistence, the use of SCC thresholds to estimate the likelihood of IMI, the choice of virulence gene sets, the methods for strain typing or to test biofilm formation, differences in species collections, and so on. This hampers true progress being made and, thus, agreement on these aspects ought to be reached among researchers.

\section{Aims of the Review}

For this review, the literature was consulted on ruminant IMI caused by CNS to get an overview of the data gathered so far on the existence of speciesrelated differences in effect on udder health, persistence capacities, and virulence, with a focus on the 5 main species Staph. chromogenes, Staph. epidermidis, Staph. haemolyticus, Staph. simulans and Staph. xylosus. We furthermore aimed to identify and discuss important knowledge gaps that currently exist and to make proposals on how to deal with essential aspects concerning CNS IMI, ultimately aiming for future research to bridge the knowledge gaps.

\section{EFFECT OF CNS ASSESSED THROUGH INFLAMMATORY RESPONSE AND MY}

\section{Effect on Inflammatory Response}

A high prevalence of IMI caused by CNS in herds characterized by low SCC might significantly con- 
tribute to the bulk milk SCC (Rainard et al., 1990; Davidson et al., 1992; Piepers et al., 2009; Sampimon et al., 2009a; Schukken et al., 2009). Nonetheless, at the cow level, CNS infections are of minor clinical importance, with the resulting mastitis symptoms being typically subclinical or mildly clinical, reflected by a low to moderate increase in SCC and other immunological parameters, and the absence of (severe) clinical signs (Hogan et al., 1987; Timms and Schultz, 1987; Davidson et al., 1992; Chaffer et al., 1999; Taponen et al., 2007; Gillespie et al., 2009; Sampimon et al., 2009a; Schukken et al., 2009; Paradis et al., 2010; Piepers et al., 2010; Persson Waller et al., 2011; Supré et al., 2011; Kalmus et al., 2013). This might be related to a low bacterial load in the milk, presumptively illustrative of a low level of colonization of the mammary gland, which appears to be typical for CNS IMI (Oikonomou et al., 2012; Kalmus et al., 2013).

Overall, effects on udder health appear to differ between CNS. For instance, experimental challenge with Staph. simulans caused slightly stronger immune responses than with Staph. epidermidis, as indicated by higher increases in SCC and other immunological parameters (Simojoki et al., 2011). That study was preceded by a pilot study (Simojoki et al., 2009) in which 5 cows challenged with a Staph. chromogenes strain all developed clinical mastitis in their challenged quarter. Although SCC, NAGase, MAA, and SAA all increased significantly compared with control quarters, only mild local signs existed, whereas systemic signs or changes in milk appearance were generally lacking (Simojoki et al., 2009). Somatic cell counts and maximum levels of SAA and MAA were considerably lower compared with the challenge study using Staph. simulans and Staph. epidermidis. However, accurate comparison of the results of both studies is hindered, as an approximately 3 times lower inoculum dose was used for Staph. chromogenes. An observational study found Staph. chromogenes, Staph. simulans, and Staph. xylosus IMI to cause an increase in quarter milk SCC not statistically significantly different from Staph. aureus IMI, although it must be noted that the power to detect differences was low (Supré et al., 2011). Other species, including Staph. epidermidis and Staph. haemolyticus, occurred at prevalence levels too low to analyze and were not considered in the analysis. Interestingly, of the 31 clinical mastitis cases identified in that study, none could be attributed to a CNS species. Thorberg et al. (2009) reported that the majority of persistent IMI with (phenotypically identified) Staph. epidermidis, Staph. simulans, and Staph. chromogenes induced a mild to strong inflammatory reaction as measured by the California mastitis test (CMT; scores 3-5), whereas persistent IMI with other CNS species, including Staph. xylosus and Staph. haemolyticus yet accounting for $<10 \%$ of cases, mostly had a low CMT score (1-2). Taponen et al. (2006) found Staph. simulans and Staph. chromogenes to cause subclinical and clinical mastitis in approximately equal proportions and no significant difference between the species was noted with respect to the severity of the symptoms in cases of clinical mastitis; other species occurred in too low numbers to draw conclusions. Persson Waller et al. (2011) detected no significant difference between the occurrence in clinical and subclinical cases for Staph. chromogenes, Staph. simulans, and Staph. haemolyticus. Yet, the proportion of subclinical cases from which Staph. epidermidis was isolated was significantly higher than the proportion of clinical cases from which Staph. epidermidis was isolated. Overall, Staph. chromogenes (29\%) and Staph. simulans $(25 \%)$ were the most prevalent species in clinical cases, with other species $<15 \%$.

Unfortunately, the results of the above-mentioned studies do not lead to workable conclusions on speciesspecific differences in effect on udder health, due to important differences in study design and investigated species. Interestingly, although several studies have also found conflicting results with regard to the effect of different CNS species on milk SCC in goat mastitis (Contreras et al., 1999; Leitner et al., 2004, 2007; Moroni et al., 2005), a recent study by Koop et al. (2012b) found only small differences between CNS species with respect to their effect on SCC, with Staph. simulans - the third most frequently encountered species - showing an insignificant yet slightly higher estimate.

Besides the 5 main species discussed above, Staphylococcus hyicus merits closer attention. In a study by Myllys (1995), Staph. hyicus was the most prevalent CNS species in clinical mastitis samples from heifers (together with Staph. simulans) and was also associated with the highest levels of milk NAGase after parturition. In addition, Waage et al. (1999) observed Staph. hyicus more often in clinical mastitis cases with systemic signs than in cases without systemic reaction, although overall Staph. simulans was the predominant species in the collection of CNS isolates from clinical mastitis (>50 vs. $<15 \%$ for all other CNS species). Whereas in the 2 latter studies phenotypic identification methods were used, a recent genotypic assessment also found the proportion of clinical mastitis cases in which Staph. hyicus was found to be significantly higher than the proportion in subclinical mastitis cases (Persson Waller et al., 2011). These findings are in line with the general picture that Staph. hyicus is 1 of the 3 major pathogenic staphylococcal species in veterinary medicine, along with Staph. aureus and species of the Staphylococcus pseudintermedius group (Staph. pseudintermedius, Staphylococcus intermedius, and Staphylococcus delphini; Hermans et al., 
2010). However, it must be noted that recently, a new staphylococcal species closely related to Staph. hyicus has been described: Staphylococcus agnetis (Taponen et al., 2012), which is very hard to distinguish from Staph. hyicus without genotypic identification methods. Hence, Staph. agnetis may have accounted for an unknown number of isolates identified as Staph. hyicus in studies using phenotypic identification methods. Staphylococcus agnetis is a relatively young species; therefore, its importance in mastitis remains to be elucidated. As Staph. hyicus has hitherto primarily been associated with pigs as a cause of exudative epidermitis (greasy pig disease), some host specificity might exist. Interestingly, whereas Staph. aureus and species of the Staph. pseudintermedius group are always coagulase positive and this trait is considered an indicator for pathogenic potential, Staph. hyicus and Staph. agnetis are known to be coagulase variable (Hermans et al., 2010; Taponen et al., 2012). All of the above-mentioned studies have delineated that the reported strains of Staph. hyicus were coagulase negative.

Coagulase-negative staphylococci have not only been reported to have a negative effect on udder health; the possibility that CNS IMI or even teat apex colonization by CNS has a positive effect on udder health is an intriguing idea that has been around for a long time (Rainard and Poutrel, 1988; Matthews et al., 1991), yet still needs further exploration. Indeed, among the most important conclusions of a recent meta-analysis of existing literature by Reyher et al. (2012b) is that challenge studies [i.e., experimental studies where the udder is challenged with (a) major pathogen(s)] show strong and significant protective effects of preexisting IMI by minor pathogens. This was particularly apparent in studies where major pathogens were introduced into the mammary gland by methods bypassing the teat end. Moreover, the protective effect was especially present for CNS (as opposed to Corynebacterium bovis). Yet, the same meta-analysis found observational studies to show no protective effect of preexisting IMI with minor pathogens. In a later study, Reyher et al. (2012a) reported that the presence of CNS 2 samplings before the occurrence of a new IMI even increased the odds of experiencing a new Staph. aureus IMI by a factor of 2 .

Some aspects of the study by Reyher et al. (2012b) need to be addressed in further detail. First, the authors only considered studies on IMI by CNS, whereas some authors have also suggested that mere colonization of the teat apices by CNS might have a protective effect. Indeed, prepartum teat apex colonization with CNS protected quarters of heifers against IMI caused by major environmental and contagious pathogens in early lactation (Piepers et al., 2011). Furthermore, quarters with teat apices colonized by Staph. chromo- genes had significantly lower odds of having a SCC $>200,000$ cells $/ \mathrm{mL}$ during the first days after calving (De Vliegher et al., 2003). These findings appear reasonable, as the naturally colonizing population can be expected to influence the entry of (major) pathogens through the teat canal. Interestingly, De Vliegher et al. (2004) subsequently found 2 out of 10 identified Staph. chromogenes isolates, originating from different teats from the same heifer, to consistently inhibit in vitro growth of all Staph. aureus, Streptococcus dysgalactiae, and Strep. uberis isolates, yet none of the E. coli isolates they tested. Another study showed Staph. epidermidis, Staph. simulans, Staphylococcus hominis, Staphylococcus saprophyticus, and Staph. arlettae isolates from milk to produce antimicrobial substances inhibiting the growth of some major mastitis pathogens, including Staph. aureus (dos Santos Nascimento et al., 2005). A second point of attention relates to the assumption that protective effects are not necessarily translated only into the prevention of major pathogen IMI. An increased MY (see below), a lower risk for culling, or a lower occurrence of clinical mastitis have all been associated with CNS IMI (Schukken et al., 2009; Piepers et al., 2010, 2013).

It must be acknowledged that ascribing a beneficial effect to the CNS as a group is probably inaccurate; such effect will rather be situated at the species or even strain level. Whereas this was recognized by Reyher et al. (2012b), they concluded that an analysis at these levels was useless, as not enough species-level data were available to generate adequate statistical power. Clearly, the lack of species and strain data needs to be dealt with if a consistent picture on a protective effect of CNS is to be generated. Moreover, elucidating the possibly protective role of $\mathrm{CNS}$ in relation to udder health should also include the mechanisms behind it, which might eventually lead to a reconsideration of the role of CNS in udder health.

\section{Effect on $M Y$}

Although agreement still exists that an IMI leads to an increase in SCC for almost all CNS species and the CNS group as a whole, the effect is less straightforward when it comes to MY, for CNS as a group as well as at the species level. In their review, Pyörälä and Taponen (2009) concluded that a slightly decreased milk production generally was the effect of an IMI by CNS, most likely associated with the increase in SCC. Yet, recent studies show another picture. For instance, CNS infections in the first month of lactation had a negative effect on test-day SCC during the entire first lactation, but no significant effect on MY (Paradis et al., 2010), even not when comparing yields between uninfected 
and CNS-infected twins, despite the increased SCC in the latter (Pearson et al., 2013). Other studies have even observed a higher milk production in CNS-infected animals relative to uninfected animals (Schukken et al., 2009; Piepers et al., 2010, 2013).

Studies at the CNS species level have shown their importance in adding more detail to the overall picture. In goats, IMI with Staph. caprae and Staph. simulans was associated with higher MY, whereas IMI with Staph. xylosus was associated with lower MY (Koop et al., 2012b), suggesting that the result of an earlier study, showing no effect on MY by CNS IMI (Koop et al., 2010), might have been due to an aggregate effect. In bovines, species-specific data on effect on MY are sparse. As mentioned above, Simojoki et al. (2009, 2011) established experimental IMI models with Staph. chromogenes, Staph. simulans, and Staph. epidermidis, showing considerable decreases in milk production during $7 \mathrm{~d}$ postchallenge. These are interesting results, because they are, so far, the only studies that provide data on the effect of CNS IMI on MY at the quarter level: important knowledge that is currently lacking. It appears that, even with CNS, a very high infection dose does lead to a negative effect on quarter MY. However, most likely, the inoculum doses used will not be reached under natural conditions and also the inoculation procedure might have contributed to the severe effect on MY. It needs to be investigated what effect CNS IMI has on quarter MY under more natural infection conditions, and this should also be investigated for other CNS species such as Staph. xylosus and Staph. haemolyticus. It might also be relevant to investigate the effect of CNS IMI in one quarter on the MY of the other quarters. As quarter-level data are generally lacking at the moment, it cannot be excluded that a negative effect in a CNS-infected quarter is always present but is compensated by some kind of extra MY in the other quarters.

A study by Thorberg et al. (2009) suggested that species-specific effects on MY are linked with persistence of IMI. Indeed, nonpersistent IMI due to Staph. epidermidis lead to significantly lower MY than persistent Staph. chromogenes or Staph. simulans IMI, whereas nonpersistent IMI due to Staph. simulans lead to significantly lower MY compared with healthy cows or cows with persistent IMI due to Staph. chromogenes, Staph. epidermidis, or Staph. simulans. In general, a significantly higher milk production was observed among persistently infected compared with nonpersistently infected cows and among healthy compared with nonpersistently infected cows. These results are intriguing and deserve further investigation, as they might indicate some sort of (positive) adaptation to IMI by the infected animal.
The fact that IMI with (some) CNS (species) is associated with higher MY might indicate that highproducing cows are somehow predetermined to acquire (CNS) IMI, obscuring an actual milk loss. Gröhn et al. (2004) reported that mature cows that developed clinical CNS mastitis during lactation were significantly higher producers before the onset of mastitis than their uninfected counterparts. However, the mechanism that might explain such a predetermination is not clear, as is the degree to which this phenomenon occurs. In other words, it needs to be established which part highproducing cows account for among CNS-infected cows and which part CNS-infected cows account for among high producers. Moreover, it would be naïve to pass a beneficial effect on MY fully to a possible predetermination of high-producing cows to attract CNS IMI and ignore CNS species-specific differences. Another, not necessarily mutually exclusive, explanation for the higher MY by CNS-infected cows is that IMI by CNS in some way exert a protective or beneficial effect on the udder. For example, a higher MY might be related to a lower risk for developing clinical mastitis, which has more detrimental effects on milk production and is a parameter directly linked to major pathogen IMI (Piepers et al., 2010). However, a recent study has found that both the lower risk for developing clinical mastitis and the genetic background for milk production played only a minor role explaining the higher MY of CNS-infected heifers (Piepers et al., 2013), leaving the exact mechanism(s) behind the positive association between CNS IMI and MY to be elucidated.

\section{PERSISTENCE OF IMI}

Although it is thought that spontaneous cure rates of CNS IMI are generally high (Harmon et al., 1986; Deluyker et al., 2005; Taponen et al., 2006), several studies have reported that CNS infections can have a long duration and sometimes persist throughout lactation (Timms and Schultz, 1987; Rainard et al., 1990; Chaffer et al., 1999; Taponen et al., 2007) or throughout the dry period (Rajala-Schultz et al., 2009). Apparently, many CNS species can cause persistent IMI in ruminants, including the 5 main species (Aarestrup et al., 1999; Taponen et al., 2007; Gillespie et al., 2009; Simojoki et al., 2009; Piessens et al., 2011; Supré et al., 2011; Koop et al., 2012b; Mørk et al., 2012), some less frequently detected species such as Staph. hyicus (Gillespie et al., 2009; Rajala-Schultz et al., 2009), Staphylococcus warneri (Taponen et al., 2007; Koop et al., 2012b; Mørk et al., 2012), Staphylococcus cohnii (Taponen et al., 2007; Supré et al., 2011), and Staphylococcus devriesei (Supré et al., 2011), and, in goats, Staph. caprae and Staphylococcus lugdunensis (Koop et al., 2012b). 
Species dependency of persistence is, however, not clear-cut. For instance, Staph. simulans has been reported to be better adapted than other CNS species to cause persistent IMI (Aarestrup and Jensen, 1997) but recent data do not confirm this (Taponen et al., 2007; Piessens et al., 2011; Mørk et al., 2012).

It appears that persistence is partly strain dependent, with several CNS species comprising strains that do cause and others that do not cause persistent IMI (Gillespie et al., 2009; Piessens et al., 2011; Mørk et al., 2012). Yet, whether the strains from a given species that cause or do not cause IMI across studies have a similar genetic background remains to be elucidated, as this requires using typing methods allowing for largescale comparisons, such as multilocus sequence typing, which has not been done so far. It is also not known by which factors strains causing persistent IMI distinguish themselves from strains not causing persistent IMI. It can be rationalized that the presence of factors granting the ability to withstand the host's immunity or external treatment will positively influence the capacity to persist in the udder. Surprisingly, an association could not be established between persistence of infection and biofilm formation in a tissue culture plate assay or a fluorescent in situ hybridization assay (Simojoki et al., 2012). Likewise, Hyvönen et al. (2009) did not observe a difference in the in vitro adhesion to and invasion of bovine mammary epithelial cells when comparing strains originating from persistent and transient IMI.

Persistence is also partly dependent on host-microbe interactions and the quality of the host's immunity. This can be deduced from the fact that in several studies, certain strains were found to cause persistent IMI in some cows and transient IMI in others (Taponen et al., 2007; Simojoki et al., 2009, 2011; Piessens et al., 2011). However, the link between immune response and persistence is not clear. In some studies, an association between persistence and severity of IMI, measured through SCC, could not be established (Taponen et al., 2007; Supré et al., 2011). In an experimental infection trial, no significant differences in serum levels of IL-1 $\beta$, IL-8, and tumor necrosis factor $\alpha$, or in SCC response and milk NAGase, MAA, and tumor necrosis factor $\alpha$ levels could be demonstrated between persistent and transient IMI caused by either Staph. epidermidis or Staph. simulans (Simojoki et al., 2011). Yet, interestingly, in persistent IMI cases, concentrations of some immune factors (IL-1 $\beta$ and IL-8) were lower, and in 2 persistent IMI cases, SAA did not increase compared with prechallenge. The latter observations are in line with an earlier experimental infection study with Staph. chromogenes by Simojoki et al. (2009) reporting that the establishment of a persistent IMI lacked an inflammatory response.
In general, studies are difficult to compare due to differing definitions of persistence and because the investigation periods are set over different stages in lactation and have other times of sampling. It is noteworthy that most studies reporting persistent IMI performed sampling on quite diverging moments in time, so it cannot be excluded that elimination and reinfection with the same strain occurred, rather than persistence. More data using molecular typing are required to confirm which strains are typical causes of persistent IMI.

\section{PUTATIVE VIRULENCE FACTORS}

\section{Biofilm Formation}

Several studies have found various CNS isolates from milk from different species to possess biofilm genes or to produce biofilms in vitro (Watts et al., 1990; BedidiMadani et al., 1998; Oliveira et al., 2006, 2007; Sawant et al., 2009; Piessens et al., 2012; Simojoki et al., 2012; Tremblay et al., 2013). Yet, these data do not permit a consistent demonstration of differences between CNS species, largely due to the variation in design of the studies. For example, Tremblay et al. (2013) found that Staph. xylosus and Staph. haemolyticus had the greatest ability to form biofilms, whereas Staph. epidermidis had the lowest ability. In contrast, Simojoki et al. (2012) observed that the biofilm formation of Staph. epidermidis was stronger compared with other CNS species. However, Staph. xylosus was not included as a separate species in the latter study (Table 1).

Some studies suggest that the majority of CNS found in milk are indeed biofilm producers, but only if granted enough time. Oliveira et al. (2007) tested the biofilmforming capacity of a collection of 29 Staph. epidermidis isolates from subclinical mastitis at 24,48 , and $72 \mathrm{~h}$ of growth, revealing that at each successive time point, a significantly larger number of isolates formed a biofilm, up to $75.9 \%$ at $72 \mathrm{~h}$. Similarly, $53 \%$ of the CNS isolated from mastitis appeared to be biofilm producers after $18 \mathrm{~h}$, using fluorescent in situ hybridization, increasing to $67 \%$ after $72 \mathrm{~h}$ (Simojoki et al., 2012). For all species described in the latter study, including Staph. chromogenes, Staph. epidermidis, Staph. haemolyticus, and Staph. simulans, an increase in biofilm formation was noted between 18 and $72 \mathrm{~h}$. This is potentially important information, as most studies commonly test biofilm production at $24 \mathrm{~h}$ of growth (Piessens et al., 2012; Tremblay et al., 2013).

The ica gene cluster appears to have a wide distribution among CNS species from various environments (Mack et al., 1996; Frebourg et al., 2000; de Silva et al., 2002; Møretrø et al., 2003; Klingenberg et al., 2007) and is traditionally regarded as the most important 


\begin{tabular}{|c|c|c|c|c|c|c|c|c|c|c|c|}
\hline \multirow[b]{2}{*}{ Tharacteristic investigated } & \multicolumn{5}{|c|}{$\begin{array}{l}\text { Main } 5 \text { CNS species }{ }^{1} \\
\text { (no. of isolates) }\end{array}$} & \multicolumn{6}{|c|}{$\begin{array}{l}\text { Other CNS species }{ }^{1} \\
\text { (no. of isolates) }\end{array}$} \\
\hline & $\begin{array}{l}S . \\
c h .\end{array}$ & $\begin{array}{c}S . \\
e p\end{array}$ & $\begin{array}{c}\text { S. } \\
\text { ha. }\end{array}$ & $\begin{array}{l}S . \\
s i .\end{array}$ & $\begin{array}{l}S . \\
x .\end{array}$ & $\begin{array}{l}S . \\
\text { eq. }\end{array}$ & $\begin{array}{c}S . \\
\text { ho. }\end{array}$ & $\begin{array}{c}S . \\
h y .\end{array}$ & $\begin{array}{l}S . \\
s c .\end{array}$ & $\begin{array}{l}S . \\
w .\end{array}$ & $\begin{array}{l}S . \\
c a .\end{array}$ \\
\hline
\end{tabular}

Result
(no. or \%

(no. or \%
of isolates)

$\mathrm{ID}^{2}$

-

Presence of biofilm

genes bap/icaA

Slime production
Negative/weak/strong biofilm
formation after $72 \mathrm{~h}$ in
FISH assay ${ }^{4}$
Presence of biofilm gene bap

(a) Biofilm formation (negative-
weak-moderate-strong);
(b) presence of biofilm genes
(none-aap-atle-bap-embP-
fbe-icaA)

55

$18 \quad 57$

41

10

22

10

(none-aap-atle-bap-embP

fbe-icaA)

Caprine

$\begin{array}{llllllr}\text { Slime production } & \text { NC } & \text { NC } & 11 & & 7 \\ & & & & 36 & & 25 \\ & & & & & 91\end{array}$

34

\section{$2.6 \%$

$42.9 \%$

$11.7 \%$

NC

NC

(1)

(a)

$0 / 0$

$8 / 3$

$34 / 0$

$0 / 9$

4

1

11-4-10-11-4

$11-2-1-2-8$

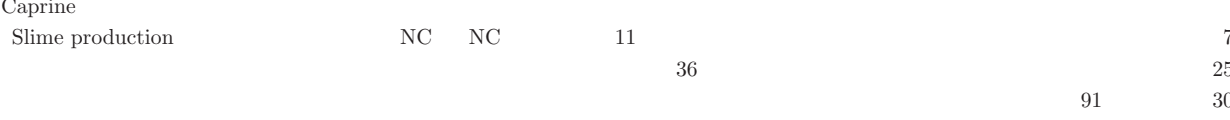

Phe + Phe-Trac

No significant within-species difference between slime-positive strains compared with slime-negative

- S. hyicus overall apparently associated with higher - S. hyicus

- Total: $41 / 366$ bap positive (11.2\%); 19/366 icaA positive $(5.2 \%)$

- 9/30 strains bap or icaA positive produced biofilm phenotypically

$\begin{array}{ll}0 / 1 & \bullet 9 / 30 \text { strains bap or icaA positive produced biofilm } \\ 0 / 0 & \text { phenotypically }\end{array}$

$14 / 15 / 12$

Phe-API + Ge-AFLP

- S. epidermidis stronger biofilm former than other 3 species in tissue culture plate assav $(P=0.01)$

\section{(a) $17-34-32-28$; (b)} $20-75-12-2-4-13-61$

Ge-rpoB

(a) 4-7-1-1; (b) 0-6-

(a) $1-5-3-6$; (b) $3-10-$

(a) $8-27-13-5$; (b)

(a) $2-2-9-12$; (b)

$0-19-3-23-3-5-12$

Significant effects:

- Biofilm formation

S. xylosus $>$ S. epidermidis and S. simulans

S. chromogenes $>$ S. simulans

S. epidermidis $>$ S. haemolyticus

S. haemolyticus > S. simulans

- Presence of biofilm genes:
icaA, bap, or fbe: positive effect on biofilm formation

icaA, bap, or fbe: positive effect on biofilm for

embP: negative effect on biofilm formation
$a a$ or $a t l E$ : no significant effect on biofilm

formation

S. ch. = Staphylococcus chromogenes; S. ep. = Staphylococcus epidermidis; S. ha. = Staphylococcus haemolyticus; S. si. $=$ Staphylococcus simulans; S. $x .=$ Staphylococcus xylosus; S. eq. $=$ Staphylococcus equorum; S. ho. = Staphylococcus hominis; S. hy. $=$ Staphylococcus hyicus; S. sc. $=$ Staphylococcus sciuri; $S$. w. $=$ Staphylococcus warneri; S. ca. $=$ Staphylococcus caprae; NC $=$ not considered, meaning some isolates of that species were identified but are not deemed relevant; blank space means no isolates were identified of that species.

${ }^{2} \mathrm{ID}$ = identification; Phe = phenotypic identification using validated morphological or biochemical characteristics, or both; Phe-32, Phe-API, and Phe-Trac = phenotypic identification using the ID32 Staph (bioMérieux SA, Marcy-l'Étoile, France), API Staph ID (bioMérieux SA), and Staph-Trac system (DMS Laboratories Inc., Flemington, NJ), respectively; Ge-AFLP and Ge-rpoB = genotypic identification using amplified fragment length polymorphism (AFLP) and

sequencing of the $r p o B$ gene, respectively.
${ }^{3}$ References (Ref.): 1 = Watts et al. (1990); 2 = Piessens et al. (2012); 3 = Simojoki et al. (2012); 4 = Tremblay et al. (2013); 5 = Bedidi-Madani et al. (1998).

${ }^{4} \mathrm{FISH}=$ fluorescence in situ hybridization. 
gene cluster associated with biofilm formation in (human associated) CNS (Otto, 2013). However, from data available to date this appears not to be the case for CNS associated with bovine milk (Table 1). In a study by Tremblay et al. (2013), icaA was only the second most common gene $(\sim 50 \%)$ in CNS isolates from bovine mastitis, after aap ( $\sim 65 \%)$. Piessens et al. (2012) identified twice as many CNS isolates carrying bap $(\sim 11 \%)$ compared with $i c a A(\sim 5 \%)$. A difficulty of the data available so far is that studies have tested for different genes. For example, Simojoki et al. (2012) and Piessens et al. (2012) did not test for aap, which was the predominant gene found in Tremblay et al. (2013). This requires attention in future studies.

Studies performing both phenotypic and genotypic tests have found apparently contradictory results of these tests. Tremblay et al. (2013) described that the 2 generally most prevailing genes $i c a A$ and aap were less frequently detected in Staph. epidermidis compared with the other 4 main species, apparently in agreement with the observed lower phenotypic ability of Staph. epidermidis to form biofilms. However, the other tested biofilm-associated genes occurred most frequently in Staph. epidermidis and this species had most isolates carrying more than 1 biofilm gene. Piessens et al. (2012) tested phenotypic biofilm production in those isolates that were found to possess 1 or more genes involved in biofilm formation but only $30 \%$ of isolates showed phenotypic biofilm formation. Hence, it is clear that future research would benefit from including a maximum of phenotypic and genotypic traits. It should also be taken in consideration that variants of known biofilm genes or yet unknown genes might be present (Allignet et al., 2001; Tormo et al., 2005; Simojoki et al., 2012), especially as most biofilm-associated genes were originally described in CNS with a human origin.

Importantly, definite proof showing that biofilm formation of CNS plays a role in the development of CNS IMI has not yet been found. Three studies have illustrated that biofilm formation is not associated with intensity of inflammation, as measured through SCC (Watts et al., 1990; Tremblay et al., 2013) or NAGase activity (Simojoki et al., 2012). Remarkably, in the latter study, isolates with more intense biofilm formation in a tissue culture plate assay tended to cause milder inflammation, although that finding was not confirmed by 2 other tested biofilm production assays. Biofilm formation is essentially a growth behavior offering protective advantages rather than a virulence factor triggering inflammatory responses in the host. Thus, biofilms would merely play a role in the establishment and maintenance of a (CNS) IMI. However, surprisingly, biofilm formation abilities appear not to be common in the CNS species found most frequently in milk.
Staphylococcus chromogenes, for instance, has not been identified as a superior biofilm producer or a very frequent biofilm gene carrier (Simojoki et al., 2012; Tremblay et al., 2013). In addition, Simojoki et al. (2012) found no association between biofilm formation and persistence of IMI. On the other hand, Tremblay et al. (2013) detected a positive association between the presence of biofilm genes and the number of DIM at which the CNS were isolated, suggesting that strong biofilm formers were selected for during lactation. Tentatively, this may be the result of a biofilm-mediated increase in the ability to persist in the mammary gland.

\section{Other Putative Virulence Factors}

Coagulase-negative staphylococci isolated from ruminant milk have been found to possess various virulence factors, such as a cytolysin acting synergistically with the Staph. aureus $\beta$-hemolysin (Watts and Owens, 1987; Bedidi-Madani et al., 1998), leukotoxins (Burriel and Dagnall, 1997), a cytotoxic metalloprotease (Zhang and Maddox, 2000), different staphylococcal enterotoxins and staphylococcal enterotoxin-like superantigens (Park et al., 2011b; Ünal and Çinar, 2012), FA-modifying enzyme (Lu et al., 2012), and various MSCRAMM genes, most importantly eno, encoding laminin-binding protein (Simojoki et al., 2012; Table 2). It has also been shown that CNS isolated from ruminant mastitis might produce elastase and bind collagen (Watts et al., 1990; Bedidi-Madani et al., 1998); might produce thermonuclease (TNAse), DNase, and show $\alpha-, \beta-$, or $\delta$-hemolysis (Bedidi-Madani et al., 1998); and might be capable of invading bovine mammary epithelial cells in vitro (Almeida and Oliver, 2001; Anaya-López et al., 2006; Hyvönen et al., 2009). Some studies have indeed proven the functionality of these factors in vitro (Watts and Owens, 1987; Burriel and Dagnall, 1997; Zhang and Maddox, 2000; Almeida and Oliver, 2001; AnayaLópez et al., 2006). However, even though it can be anticipated that adhesion factors, immune-responsive factors, and tissue-degrading factors might all play a role in IMI and mastitis, the concrete function of the factors summarized above has so far not been adequately substantiated. Until now, it has not been possible to find reliable associations between certain (combinations of) virulence factors and the severity of mastitis (Watts and Owens, 1987; Watts et al., 1990; Bedidi-Madani et al., 1998; Lu et al., 2012; Simojoki et al., 2012). The possibility thus exists that the factors identified are not the actual ones affecting udder health or that their potential is not fully expressed in CNS causing IMI; for example, through inhibition exerted by host factors or competitive bacterial species. Alternatively, as for immune evasion factors such as internalization in 


\begin{tabular}{|c|c|c|c|c|c|c|}
\hline \multicolumn{5}{|c|}{$\begin{array}{l}\text { Main } 5 \text { CNS species }{ }^{1} \\
\text { (no. of isolates) }\end{array}$} & \multicolumn{2}{|c|}{$\begin{array}{r}\text { Other } \mathrm{C} \\
\text { (no. o }\end{array}$} \\
\hline $\begin{array}{l}S . \\
c h .\end{array}$ & $\begin{array}{l}S . \\
e p .\end{array}$ & $\begin{array}{l}S . \\
h a .\end{array}$ & $\begin{array}{l}S \text {. } \\
\text { si. }\end{array}$ & $\begin{array}{l}S . \\
x .\end{array}$ & $\begin{array}{l}S . \\
e q .\end{array}$ & $\begin{array}{l}S . \\
\text { ho. }\end{array}$ \\
\hline & 1 & & & 1 & & \\
\hline \multirow{3}{*}{38} & 1 & 1 & & 1 & 2 & \\
\hline & & & & & & \\
\hline & 28 & & & & & \\
\hline
\end{tabular}

S. S. S. S.

$\begin{array}{lccccccccccc} & S . & S . & S . & S . & S . & S . & S . & S . & S . & S . & S . \\ \text { Characteristic investigated } & c h . & \text { ep. } & \text { ha. } & \text { si. } & x . & \text { eq. } & \text { ho. } & \text { hy. } & \text { sc. } & \text { w. } & \text { ca }\end{array}$

Bovine

Adherence to and

internalization in bovine

(1) The

ry epithelial cells

1

Result

$\mathrm{ID}^{2}$

Remark

Ref. $^{3}$

S. xylosus $>$ S. hyicus $>$ S. $\quad$ NAS

genes $b b p$, clf $A$, clfB, cna

ebpS, eno, fib, fnbA, fnbB

18

24

Presence of enterotoxin

genes a-e and $\mathrm{g}-\mathrm{j}$,

enterotoxin-like genes

$\mathrm{k}-\mathrm{q}$ and $\mathrm{u}$, and genes tst 1 ,

$$
\text { eta, etb }
$$

Presence of enterotoxin

genes a-e and $\mathrm{g}-\mathrm{i}$,

enterotoxin-like genes

$\mathrm{j}-\mathrm{r}$ and $\mathrm{u}$, and gene tst 1
Only internalization by $S$.

Ge-ribo

epidermidis strain

(a) $2.6 \%$; (b) $6.6 \%-4.2 \%$

$\begin{array}{ll}\text { Phe + Phe- } & \text { No significant within-specie } \\ \text { Trac } & \text { differences between collagen- }\end{array}$

(a) $39.3 \%$; (b) $5.8 \%-4.3 \%$

(a) $1.1 \%$; (b) $7.4 \%-4.9 \%$

or elastase-positive strains

compared with negative

strains

- S. hyicus overall apparently

associated with higher SCC-

ebpS (2), eno (20), fib (1)

Phe-API +

levels

eno (10)

clfA (2), clfB (2), ebpS (1), eno

(18), fib (2), fnbA (2), fnbB (2)

$b b p$ (1), clfA (1), clfB (1), ebpS

(1), eno (5), fib (1), fnbA (1)

0 positive isolates

Phe + Phe-

API + Ge-

tDNA

2

3

42 positive isolates $(22.1 \%)$ : sea Ge- $16 \mathrm{~S}$

(4), seb (33), sec (1), sed (1), rRNA +

selj (2), selk (4), seln (33), selq Ge-rpoB

$(37)$, selr $(1)$, selu (3)

1 positive isolate $(50 \%)$ : seg

(1), seh (1)

6 positive isolates (37.5\%): seb

(3), sed (1), selj (3), seln (3),

selq (3)

5 positive isolates $(71.4 \%)$ : seb

(3), sed (1), sei (1), seln (3),

selq (3)

11 positive isolates $(45.8 \%)$ : seb

(9), seg (1), seln (9), selo (1),

selq $(9)$, selu (1)

8 positive isolates (100\%): seb

(4), sec (2), sed (3), selk (7),

seln $(4)$, selq $(4)$

7 positive isolates $(77.8 \%)$ : seb

$(2)$, sei (4), selk (1), seln (2),

selq (2) 
Table 2 (Continued). Other virulence factors of coagulase-negative Staphylococcus species originating from bovine, ovine, or caprine milk samples

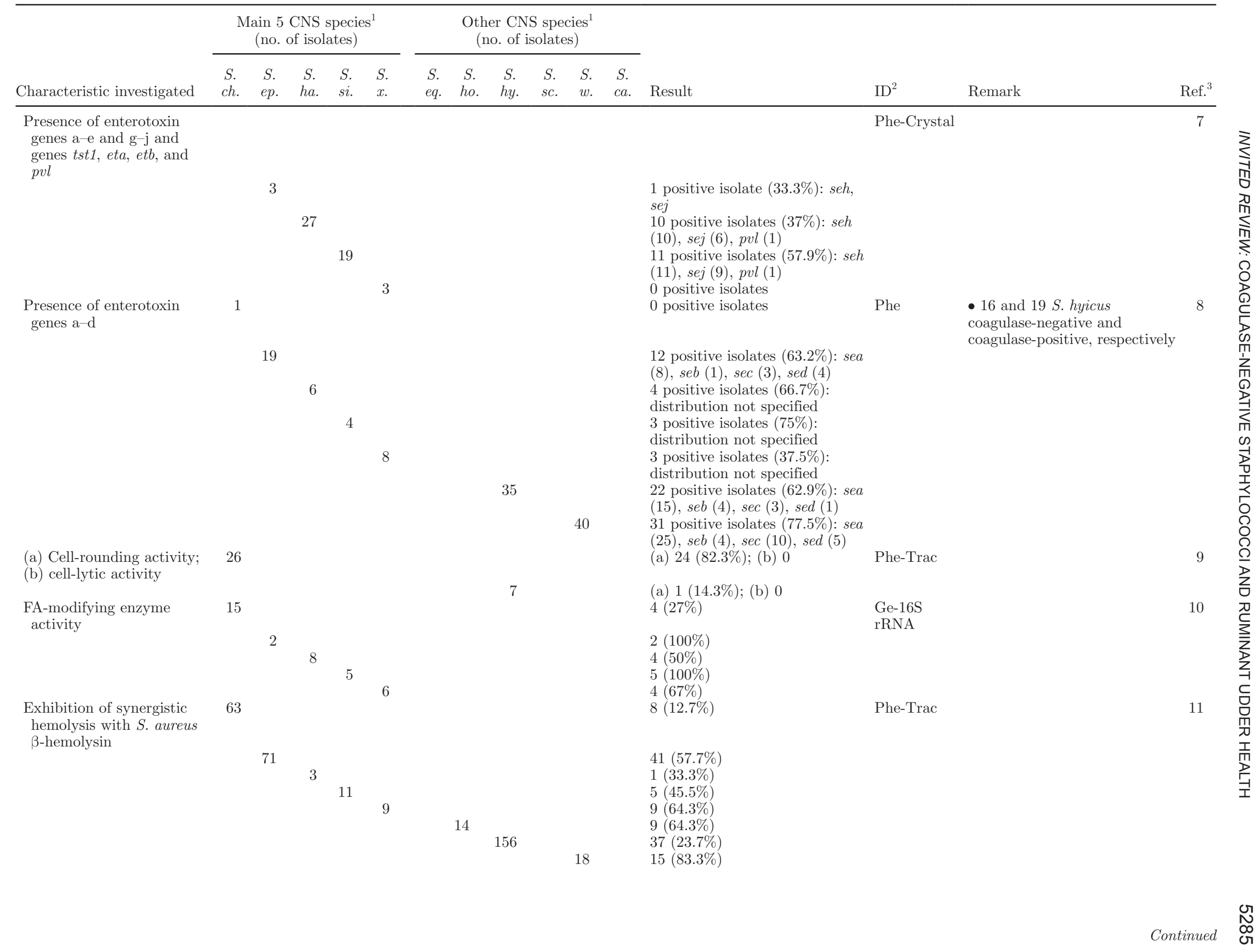




\begin{tabular}{|c|c|c|}
\hline & & ain 5 \\
\hline Characteristic investigated & $\begin{array}{l}S . \\
c h\end{array}$ & $\begin{array}{c}S . \\
e p .\end{array}$ \\
\hline $\begin{array}{l}\text { Ovine } \\
\text { Presence of enterotoxin } \\
\text { genes a-e and } \mathrm{g}-\mathrm{j} \text {, and } \\
\text { genes } t s t 1 \text {, eta, etb and } \\
\text { pvl }\end{array}$ & & \\
\hline $\begin{array}{l}\text { Caprine } \\
\text { (a) Display of } \alpha--\beta--\delta- \\
\text { hemolysis; (b) TNAse-- } \\
\text { DNase activity }{ }^{6} \text {; } \\
\text { (c) elastase activity }\end{array}$ & $\mathrm{NC}$ & $\mathrm{NC}$ \\
\hline
\end{tabular}

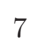

4

11

36
Other CNS species ${ }^{1}$ (no. of isolates)

${ }^{1}$ S. ch. $=$ Staphylococcus chromogenes $;$ S. ep. $=$ Staphylococcus epidermidis; S. ha. = Staphylococcus haemolyticus; S. si. $=$ Staphylococcus simulans; S. x. $=$ Staphylococcus xylosus; S. eq. = Staphylococcus equorum; S. ho. = Staphylococcus hominis; S. hy. = Staphylococcus hyicus; S. sc. = Staphylococcus sciuri; S. w. = Staphylococcus warneri; S. ca. $=$ Staphylococcu. caprae; $\mathrm{NC}=$ not considered, meaning some isolates of that species were identified but are not deemed relevant; blank space means no isolates were identified of that species.

${ }^{2} \mathrm{ID}$ = identification; NAS = not adequately specified; Phe = phenotypic identification using validated morphological or biochemical characteristics, or both; Phe-API, Phe-32, Phe-

Trac, and Phe-Crystal = phenotypic identification using API Staph ID (bioMérieux SA, Marcy-l'Étoile, France), ID32 Staph system (bioMérieux SA), Staph-Trac system (DMS Laboratories Inc., Flemington, NJ), and Crystal Gram-Positive Kit (Becton, Dickinson and Co., Franklin Lakes, NJ), respectively; Ge-ribo, Ge-AFLP, Ge-16S rRNA, Ge-rpoB, and Ge-tDNA = genotypic identification using ribotyping, amplified fragment length polymorphism (AFLP), sequencing of 16S rRNA gene, sequencing of rpoB gene, and transfer DNA intergenic spacer PCR, respectively.

${ }^{3}$ References (Ref.): 1 = Almeida and Oliver (2001); 2 = Anaya-López et al. (2006); $3=$ Watts et al. (1990); $4=$ Simojoki et al. (2012); $5=$ Nemati et al. (2008); $6=$ Park et al. (2011b); 7 = Ünal and Çinar (2012); 8 = de Freitas Guimarães et al. (2013); 9 = Zhang and Maddox (2000); $10=$ Lu et al. (2012); $11=$ Watts and Owens (1987); 12 = BedidiMadani et al. (1998).

${ }^{4} \mathrm{MAC}-\mathrm{T}$ cells $=$ bovine mammary alveolar cells

${ }^{5}$ MSCRAMM $=$ microbial surface components recognizing adhesive matrix molecules.

${ }^{6}$ TNAse $=$ thermonuclease. 
epithelial cells, the lack of an association between their presence and health parameters such as SCC might actually prove their functionality.

Generally, differences in the virulence capacity of CNS species found in mastitis seem to be present, although a consistent picture is still lacking. Several early studies used phenotypic identification methods and their results, though interesting, should thus be interpreted with care (Table 2). Watts and Owens (1987) found high to very high percentages of Staph. epidermidis, Staph. hominis, Staph. simulans, and Staph. warneri isolates from milk to act synergistically with the Staph. aureus $\beta$-hemolysin, whereas this feature was only present in a low to moderate number of Staph. chromogenes, Staph. hyicus, and Staph. xylosus isolates. According to Watts et al. (1990), collagen binding was in the same range for Staph. chromogenes, Staph. epidermidis, and Staph. hyicus, whereas elastase production was markedly higher in Staph. epidermidis than in the other 2 species. In goats, Bedidi-Madani et al. (1998) found Staph. caprae strains to typically show frequent $\beta$ - and $\delta$-hemolysis but less likely $\alpha$-hemolysis, and to typically be positive for elastase and DNase activity but not TNAse activity or slime production. In contrast, Staph. xylosus more often showed $\alpha$-hemolysis than $\beta$ - and $\delta$-hemolysis, and was more frequently positive for slime production and less for elastase, TNAse, or DNase activity. Third, Staph. simulans was found to frequently show $\alpha-, \beta-$, and $\delta$-hemolysis, and to be positive for TNAse and elastase activity and slime production, whereas it rather infrequently showed DNase activity. In a study by Zhang and Maddox (2000), a markedly higher number of Staph. chromogenes had cell-rounding cytotoxic activity compared with Staph. hyicus. Other studies have compared adhesion and internalization capacities of different CNS species. Almeida and Oliver (2001) compared single strains of Staph. epidermidis, Staph. xylosus, and Staph. hyicus and found Staph. xylosus to adhere and internalize best. In contrast, Anaya-López et al. (2006), using 1 or 2 strains per species, found Staph. epidermidis to show much better internalization than Staphylococcus equorum, Staph. haemolyticus, and Staph. xylosus. Hyvönen et al. (2009) found no pronounced differences between species, instead observing large within-species variation in adhesion and invasion capacity for Staph. chromogenes, Staph. epidermidis, Staph. haemolyticus, and Staph. simulans.

Except for the latter, the abovementioned studies used phenotypic methods for species identification. Using genotypic methods, Lu et al. (2012) tested 13 CNS species for their FA-modifying enzyme activity. Among the 5 main species, large differences were found in the percentage of isolates showing FA-modifying enzyme activity, with Staph. simulans and Staph. epidermidis showing the highest and Staph. chromogenes the lowest percentages. However, these results need to be interpreted with care due to the low number of isolates (between 2 and 15) tested per species (Table 2). Notably, significant within-species variation in FA-modifying enzyme activity over time was observed. Simojoki et al. (2012) identified Staph. simulans and Staph. haemolyticus as the highest producers of MSCRAMM compared with Staph. epidermidis, Staph. chromogenes, and a group of unidentified isolates. Yet, in general, only 1 or 2 isolates of these species were positive for the tested genes. Park et al. (2011b) found high percentages of superantigenpositive isolates among Staph. hyicus, Staphylococcus sciuri (ssp. carnaticus), and Staph. simulans, whereas moderate numbers appeared for Staph. xylosus, Staph. haemolyticus, and Staph. chromogenes. Overall, seb, seln, and selq were the most frequently occurring toxin genes, whereas see, sell, selm, selp, and tst1 were not detected. In contrast, de Freitas Guimarães et al. (2013), using phenotypic identification, tested for the presence of sea, seb, sec, and sed, and found sea to be the predominant gene. Staphylococcus warneri isolates showed a greater percentage of sea than seb, sec, or sed, whereas Staph. hyicus isolates showed a greater percentage of sea than sec. As only a single Staph. chromogenes and few Staph. simulans, Staph. xylosus, and Staph. haemolyticus were isolated, the reliability of the species identification results may be questioned. This also accounts for another recent study by Ünal and Çinar (2012) in which the presence of superantigens was tested in $18 \mathrm{CNS}$ species originating from bovine and ovine IMI. No Staph. chromogenes and almost no Staph. caprae were found in that study, possibly related to the use of a Crystal Gram-Positive Kit (Becton, Dickinson and Co., Franklin Lakes, NJ), as this can be expected to perform poor in identification, being designed to differentiate among gram-positive genera and species. Staphylococcus capitis, Staph. simulans, and Staph. haemolyticus were the species with the highest numbers of isolates possessing at least 1 staphylococcal enterotoxin and the combination seh-sej was the most common. In contrast to the latter 3 reports, in a study testing 102 CNS isolates, including predominantly Staph. xylosus, Staph. chromogenes, and Staph. epidermidis, Nemati et al. (2008) found not one isolate positive for any of the tested genes, even though a wide range of genes was tested. Possibly, the fairly different results of the latter 4 studies might in part be explained by the use of different primer sets to detect the target genes. 
METHODOLOGICAL CONSIDERATIONS AND AREAS FOR FUTURE RESEARCH

\section{Methodological Proposals for Future Research}

Throughout this review, we have identified several weaknesses in our current understanding of the clinical effect, persistence, and potential virulence of CNS species associated with ruminant udder health. These generally relate to the difficulty of drawing consistent conclusions from the multitude of data that have been gathered, due to the fact that the studies that have yielded the data often differ in several, sometimes essential, aspects or lack enough observations on particular CNS species. In general, the problems are situated at 3 levels: (1) the use of different definitions (e.g., for IMI and persistence); (2) the different composition of the collections of isolates being studied, both with respect to the number of isolates per species and the origin of the isolates (e.g., heifers vs. multiparous cows, low-SCC herds vs. high-SCC herds, lactation vs. dry period, and so on); and (3) the lack of an objective basis (i.e., at the molecular level) for comparing isolates from a given species from different studies. To gain true progress in our understanding of CNS IMI, it is of utmost importance that future research takes these problems into account and tailors studies to each other and to the existing knowledge gaps. Some considerations and recommendations on how to approach these 3 levels in the future are listed below.

First, the use of different definitions is probably the easiest problem to solve; indeed, it merely requires that agreement is found on a definition and subsequently that this definition is consistently used. Concerning the definition of a quarter as having or not having an IMI, in a series of 4 studies, the topic was addressed of accurately defining an IMI and the IMI status of a quarter by developing a consensus gold standard based on 3 consecutive milk samples (Andersen et al., 2010), by investigating the value of diagnosing an IMI based on a single milk sample (Dohoo et al., 2011b), by evaluating the merits of duplicate and triplicate sampling compared with deciding based on a single sample (Dohoo et al., 2011a), and by evaluating the accuracy of a cow-level diagnosis based on a composite sample compared with a set of quarter samples (Reyher and Dohoo, 2011). Giving a detailed overview of their results would lead us too far, even if only CNS would be included. However, it appears that one definition is the most feasible to conclude a quarter to have a CNS IMI: 2 or more colonies that are isolated from a single 0.01-mL milk sample, either in mixed growth or pure culture, without a SCC threshold to be regarded (Dohoo et al., 2011b). We propose this definition to be used henceforth, until more research provides better definitions.

Concerning the definition of a persistent IMI, this has not yet been addressed in a similar profound manner. The most accurate definition might be that a persistent IMI can be concluded when several consecutive samples, collected at time intervals that are short enough to exclude the occurrence of a new/ acute infection, show IMI-following the definition of Dohoo et al. (2011a) - that is caused by the identical pathogenic agent, as established using an appropriate molecular typing tool [i.e., able to detect small-scale genomic changes, such as pulsed-field gel electrophoresis (PFGE), randomly amplified polymorphic DNA (RAPD), or amplified fragment length polymorphism (AFLP)]. Evidently, however, this definition suffers from the lack of knowledge on what is a "short enough" time interval. Furthermore, the question can be posed how many consecutive samplings should be taken to conclude it indeed concerns a persistent IMI. Yet, in anticipation of more consensus being found in the future on these issues, the "ideal" definition given above at least allows to assess the merits of any definition used. Indeed, the reliability to conclude that an IMI is persistent decreases (1) if only genotypic species identification has been performed rather than strain typing, (2) if the interval between samplings increases, and (3) with a decreasing number of consecutive samples having been taken.

Second, the presence of different species in the collections of isolates is something a priori out of reach of the researcher. However, obviously, the larger the study (i.e., the more samples taken and the more isolates collected), the higher the chance of having sufficient numbers of isolates of each species available to draw some conclusions on aspects of that particular species. If this cannot be achieved, for example due to funding issues, an intrinsic low number of feasible study objects in a country or region or the fact that certain CNS species simply are present in low numbers, researchers should aim to design multicenter and even international studies. Isolates should also easier be exchanged between research groups, or be available through a central database. An interesting and valuable example of how different mastitis stakeholders might collaborate and make beneficial use of large data collections obtained through uniform procedures is found in the Canadian Bovine Mastitis Research Network, consisting of the National Cohort of Dairy Farms, the Mastitis Laboratory Network, and the Mastitis Pathogen Culture Collection (Reyher et al., 2011). Similar initiatives might be set up within or preferably between other countries. 
When sharing collections of isolates, attention should be paid to the origin of the isolates, as delineated above (e.g., heifers vs. multiparous cows, low-SCC herds vs. high-SCC herds, lactation vs. dry period, and so on). Evidently, which kinds of samples are taken depends on the scope and specific research questions of a particular study and general recommendations are not of use here. However, it might help if the materials and methods and results sections are as comprehensive as possible, even if this might exceed the actual needs for answering the specific research questions. Such additional information can be provided in annexes so that other researchers have access to this information, which could provide, for example, a basis for exchange of isolates. Moreover, some test methods can be generalized between studies, specifically in relation to the topics addressed in this review. To study the effect on udder health, at least quarter-level SCC data should be provided, and for MY quarter-level production data. To test biofilm formation, both phenotypic and genotypic tests should be applied. Genotypic tests should always include $i c a$, bap, and $a a c$, whereas testing for other genes is at will of the researcher or might be decided based on the result of the phenotypic tests (e.g., if an incongruence exists in genotypic and phenotypic results). For phenotypic tests, at least 2 methods should always be performed: plate count assay and Congo red agar. Exact percentages should always be provided. Biofilm production should certainly also be tested for more than $24 \mathrm{~h}$. We propose to always check at least at 24,48 , and $72 \mathrm{~h}$. Finally, for testing of potential virulence genes, giving general recommendations is unfeasible, as this is largely dependent on the scope of the study. However, researchers should pay much attention to carefully selecting the study and control population(s) of isolates and investigate representative isolates from both populations genotypically.

Third, the need for an objective molecular basis for comparison of isolates within CNS species is essential, to gain more understanding of mastitis caused by different CNS species as well as to learn more about the species itself. For Staph. aureus, such methods are available and have yielded interesting results (e.g., Smith et al., 2005). Hence, it is of utmost importance that for at least the 5 main species, typing methods are validated that allow small-scale epidemiological and long-term, large-scale, and possibly evolutionary research (e.g., pulsed-field gel electrophoresis and multilocus sequence typing, respectively).

\section{Future Areas of Research}

If attention would be given to the points raised above, many specific research questions will be addressed with greater efficiency. Considering that MY is one of the most directly appreciable parameters for dairy farmers, perhaps the most urgent studies needed in CNS mastitis research are those aimed at identifying all factors influencing the outcome of a CNS IMI. In general, a need exists to link the presence of virulence factors to a specific behavior of CNS in mastitis, taking into account the host's immune status. It also remains to be revealed whether biofilm formation plays any role at all in IMI and through which mechanisms. Furthermore, it needs to be evaluated if Staph. chromogenes, Staph. simulans, and Staph. hyicus/Staph. agnetis are indeed species with a more severe effect on udder health and, if so, by which mechanism. It is important to further substantiate if some CNS species should be regarded as true (minor) pathogens or as harmless commensals. This is especially important, as the health-promoting role of commensals is increasingly being recognized (e.g., Human Microbiome Project Consortium, 2012). Accordingly, it has been suggested that care should be taken using the term virulence factors; the exact same factors might actually be determining the commensal or beneficial behavior in other circumstances. The term niche factor has been proposed as an alternative to be given under appropriate conditions (Hill, 2012). Finally, it needs to be resolved to which degree biofilm formation, virulence, and clinical effects are to be situated at strain level, and whether the strains from a given species that show a certain behavior have a similar genetic background across different studies.

\section{CONCLUSIONS}

Much improvement has been made from the traditionally held view, not even $10 \mathrm{yr}$ old, that CNS involved in ruminant IMI are a homogeneous group of organisms. Molecular identification techniques have enabled us to gain reliable species data, and $5 \mathrm{CNS}$ species have been identified as more common or more important. Although CNS as a group have a limited effect on udder health and MY, evidence is now available showing that differences exist among CNS species in their typical effects. Specifically, Staph. chromogenes, Staph. simulans, and the Staph. hyicus/Staph. agnetis group might play a more important role when it comes to udder health. Results also suggest that (some) CNS (species) have a positive effect on MY. However, which species are involved and by which mechanism they operate remain to be revealed. A link with the capacity to cause persistent IMI should be further investigated. It is now clear that several species of CNS are capable of causing persistent infections, contrary to what was long believed. Yet, more than other aspects of CNS mastitis, data suggest that this trait is strain dependent, and 
also that the host appears to play a role. The bacterial factors associated with the behavior of CNS in IMI are less clear. Supposedly, biofilm formation might be inivolved; however, the evidence on a role of biofilm formation in establishment and maintenance of IMI is, to date, indirect and inconclusive. Coagulase-negative staphylococci species-specific differences in biofilm formation are not (yet) apparent; it seems clear, however, that biofilm formation is not involved in the clinical effects of CNS IMI. Various virulence factors have been identified in different CNS species isolated from milk, for some of which an in vitro activity has been indicated. However, which factors are truly involved in CNS pathogenicity in mastitis and in which manner basically remains unclear. In several studies, CNS species were described to contain some or other different virulence factors but a consistent picture of which species might be more virulent and by which factors exactly is not (yet) available.

Overall, much work has already been done, but unfortunately, little can as yet truly be learned. That is a pity and it is probably wise to avoid the same conclusion having to be drawn in another $5 \mathrm{yr}$. The main obstacle appears to be the difficulty in comparing the performed studies, due to large variations in study design and collection of isolates. Hence, future research would benefit from tuning studies to each other and to the existing knowledge gaps. Doing so would lead to a more productive approach regarding numerous research questions. One of the more interesting among the research questions is the exact importance of the strain level in determining the conflicting observations concerning the importance of CNS for udder health.

\section{REFERENCES}

Aarestrup, F. M., and N. E. Jensen. 1997. Prevalence and duration of intramammary infection in Danish heifers during the peripartum period. J. Dairy Sci. 80:307-312.

Aarestrup, F. M., H. D. Larsen, and N. E. Jensen. 1999. Characterization of Staphylococcus simulans strains isolated from cases of bovine mastitis. Vet. Microbiol. 66:165-170.

Allignet, J., S. Aubert, K. G. H. Dyke, and N. El Solh. 2001. Staphylococcus caprae strains carry determinants known to be involved in pathogenicity: A gene encoding an autolysin-binding fibronectin and the $i c a$ operon involved in biofilm formation. Infect. Immun. 69:712-718.

Almeida, R. A., and S. P. Oliver. 2001. Interaction of coagulase-negative Staphylococcus species with bovine mammary epithelial cells. Microb. Pathog. 31:205-212.

Anaya-López, J. L., O. E. Contreras-Guzmán, A. Cárabez-Trejo, V. M. Baizabal-Aguirre, J. E. López-Meza, J. J. Valdez-Alarcón, and A. Ochoa-Zarzosa. 2006. Invasive potential of bacterial isolates associated with subclinical bovine mastitis. Res. Vet. Sci. 81:358361.

Andersen, S., I. R. Dohoo, R. Olde Riekerink, H. Stryhn, and Mastitis Research Workers' Conference. 2010. Diagnosing intramammary infections: Evaluating expert opinions on the definition of intramammary infection using conjoint analysis. J. Dairy Sci. 93:2966-2975.
Arvidson, S. 2006. Extracellular enzymes. Pages 478-485 in GramPositive Pathogens. 2nd ed. V. A. Fischetti, R. P. Novick, J. J. Ferretti, D. A. Portnoy, and J. I. Rood, ed. ASM Press, Washington, DC

Atanasova, K., S. Van Gucht, F. Barbé, L. Duchateau, and K. Van Reeth. 2011. Lipoteichoic acid from Staphylococcus aureus exacerbates respiratory disease in porcine respiratory coronavirus-infected pigs. Vet. J. 188:210-215.

Bedidi-Madani, N., T. Greenland, and Y. Richard. 1998. Exoprotein and slime production by coagulase-negative staphylococci isolated from goats' milk. Vet. Microbiol. 59:139-145.

Braem, G., S. De Vliegher, K. Supré, F. Haesebrouck, F. Leroy, and L. De Vuyst. 2011. (GTG) $)_{5}$ PCR fingerprinting for the classification and identification of coagulase-negative Staphylococcus species from bovine milk and teat apices: A comparison of type strains and field isolates. Vet. Microbiol. 147:67-74.

Burriel, A. R., and G. J. R. Dagnall. 1997. Leukotoxic factors produced by staphylococci of ovine origin. Microbiol. Res. 152:247-250.

Capurro, A., K. Artursson, K. Persson Waller, B. Bengtsson, H. Ericsson-Unnerstad, and A. Aspán. 2009. Comparison of a commercialized phenotyping system, antimicrobial susceptibility testing, and tuf gene sequence-based genotyping for species-level identification of coagulase-negative staphylococci isolated from cases of bovine mastitis. Vet. Microbiol. 134:327-333.

Chaffer, M., G. Leitner, M. Winkler, A. Glickman, O. Krifucks, E. Ezra, and A. Saran. 1999. Coagulase-negative staphylococci and mammary gland infections in cows. Zentralbl. Veterinärmed B 46:707-712.

Christensen, G. D., W. A. Simpson, J. J. Younger, L. M. Baddour, F. F. Barrett, D. M. Melton, and E. H. Beachey. 1985. Adherence of coagulase-negative staphylococci to plastic tissue culture plates: A quantitative model for the adherence of staphylococci to medical devices. J. Clin. Microbiol. 22:996-1006.

Christner, M., G. C. Franke, N. N. Schommer, U. Wendt, K. Wegert, P. Pehle, G. Kroll, C. Schulze, F. Buck, D. Mack, M. Aepfelbacher, and H. Rohde. 2010. The giant extracellular matrix-binding protein of Staphylococcus epidermidis mediates biofilm accumulation and attachment to fibronectin. Mol. Microbiol. 75:187-207.

Clutterbuck, A. L., E. J. Woods, D. C. Knottenbelt, P. D. Clegg, C. A. Cochrane, and S. L. Percival. 2007. Biofilms and their relevance to veterinary medicine. Vet. Microbiol. 121:1-17.

Contreras, A., M. J. Paape, and R. H. Miller. 1999. Prevalence of subclinical intramammary infection caused by Staphylococcus epidermidis in a commercial dairy goat herd. Small Rumin. Res. $31: 203-208$

Corrigan, R. M., D. Rigby, P. Handley, and T. J. Foster. 2007. The role of Staphylococcus aureus surface protein SasG in adherence and biofilm formation. Microbiology 153:2435-2446.

Cucarella, C., C. Solano, J. Valle, B. Amorena, Í. Lasa, and J. R. Penadés. 2001. Bap, a Staphylococcus aureus surface protein involved in biofilm formation. J. Bacteriol. 183:2888-2896.

Davidson, T. J., I. R. Dohoo, A. W. Donald, H. Hariharan, and K Collins. 1992. A cohort study of coagulase negative staphylococcal mastitis in selected dairy herds in Prince Edward Island. Can. J. Vet. Res. 56:275-280.

de Freitas Guimarães, F., D. B. Nóbrega, V. B. Richini-Pereira, P. M. Marson, J. C. de Figueiredo Pantoja, and H. Langoni. 2013. Enterotoxin genes in coagulase-negative and coagulase-positive staphylococci isolated from bovine milk. J. Dairy Sci. 96:28662872.

de Silva, G. D. I., M. Kantzanou, A. Justice, R. C. Massey, A. R. Wilkinson, N. P. J. Day, and S. J. Peacock. 2002. The ica operon and biofilm production in coagulase-negative staphylococci associated with carriage and disease in a neonatal intensive care unit. J. Clin. Microbiol. 40:382-388.

De Vliegher, S., L. K. Fox, S. Piepers, S. McDougall, and H. W. Barkema. 2012. Invited review: Mastitis in dairy heifers: Nature of the disease, potential impact, prevention, and control. J. Dairy Sci 95:1025-1040

De Vliegher, S., H. Laevens, L. A. Devriese, G. Opsomer, J. L. M. Leroy, H. W. Barkema, and A. de Kruif. 2003. Prepartum teat 
apex colonization with Staphylococcus chromogenes in dairy heifers is associated with low somatic cell count in early lactation. Vet. Microbiol. 92:245-252.

De Vliegher, S., G. Opsomer, A. Vanrolleghem, L. A. Devriese, O. C. Sampimon, J. Sol, H. W. Barkema, F. Haesebrouck, and A. de Kruif. 2004. In vitro growth inhibition of major mastitis pathogens by Staphylococcus chromogenes originating from teat apices of dairy heifers. Vet. Microbiol. 101:215-221.

Dedent, A. C., L. A. Marraffini, and O. Schneewind. 2006. Staphylococcal sortases and surface proteins. Pages 486-495 in GramPositive Pathogens. 2nd ed. V. A. Fischetti, R. P. Novick, J. J. Ferretti, D. A. Portnoy, and J. I. Rood, ed. ASM Press, Washington, DC.

Deluyker, H. A., S. N. Van Oye, and J. F. Boucher. 2005. Factors affecting cure and somatic cell count after pirlimycin treatment of subclinical mastitis in lactating cows. J. Dairy Sci. 88:604-614.

Dohoo, I., S. Andersen, R. Dingwell, K. Hand, D. Kelton, K. Leslie, Y. Schukken, and S. Godden. 2011a. Diagnosing intramammary infections: Comparison of multiple versus single quarter milk samples for the identification of intramammary infections in lactating dairy cows. J. Dairy Sci. 94:5515-5522.

Dohoo, I. R., J. Smith, S. Andersen, D. F. Kelton, and S. Godden., and Mastitis Research Workers' Conference. 2011b. Diagnosing intramammary infections: Evaluation of definitions based on a single milk sample. J. Dairy Sci. 94:250-261.

dos Santos Nascimento, J., P. C. Fagundes, M. A. V. de Paiva Brito, K. R. N. dos Santos, and M. do Carmo de Freire Bastos. 2005. Production of bacteriocins by coagulase-negative staphylococci involved in bovine mastitis. Vet. Microbiol. 106:61-71.

Ferens, W. A., W. C. Davis, M. J. Hamilton, Y. H. Park, C. F. Deobald, L. Fox, and G. Bohach. 1998. Activation of bovine lymphocyte subpopulations by staphylococcal enterotoxin C. Infect. Immun. 66:573-580.

Frebourg, N. B., S. Lefebvre, S. Baert, and J.-F. Lemeland. 2000. PCR-based assay for discrimination between invasive and contaminating Staphylococcus epidermidis strains. J. Clin. Microbiol. 38:877-880.

Freeman, D. J., F. R. Falkiner, and C. T. Keane. 1989. New method for detecting slime production by coagulase negative staphylococci. J. Clin. Pathol. 42:872-874.

Gillespie, B. E., S. I. Headrick, S. Boonyayatra, and S. P. Oliver. 2009. Prevalence and persistence of coagulase-negative Staphylococcus species in three dairy research herds. Vet. Microbiol. 134:65-72.

Gröhn, Y. T., D. J. Wilson, R. N. Gonzalez, J. A. Hertl, H. Schulte, G. Bennett, and Y. H. Schukken. 2004. Effect of pathogen-specific clinical mastitis on milk yield in dairy cows. J. Dairy Sci. 87:3358-3374.

Harmon, R. J., W. L. Crist, R. W. Hemken, and B. E. Langlois. 1986. Prevalence of minor udder pathogens after intramammary dry treatment. J. Dairy Sci. 69:843-849.

Heilmann, C., O. Schweitzer, C. Gerke, N. Vanittanakom, D. Mack, and F. Götz. 1996. Molecular basis of intercellular adhesion in the biofilm-forming Staphylococcus epidermidis. Mol. Microbiol. 20:1083-1091.

Hermans, K., L. A. Devriese, and F. Haesebrouck. 2010. Staphylococcus. Pages 75-89 in Pathogenesis of Bacterial Infections in Animals. 4th ed. C. L. Gyles, J. F. Prescott, G. Songer, and C. O. Thoen, ed. Wiley-Blackwell, Danvers, MA.

Hill, C. 2012. Virulence or niche factors: What's in a name? J. Bacteriol. 194:5725-5727.

Hogan, J. S., D. G. White, and J. W. Pankey. 1987. Effects of teat dipping on intramammary infections by staphylococci other than Staphylococcus aureus. J. Dairy Sci. 70:873-879.

Hyvönen, P., S. Käyhkö, S. Taponen, A. von Wright, and S. Pyörälä. 2009. Effect of bovine lactoferrin on the internalization of coagulase-negative staphylococci into bovine mammary epithelial cells under in vitro conditions. J. Dairy Res. 76:144-151.

Kalmus, P., H. Simojoki, S. Pyörälä, S. Taponen, J. Holopainen, and T. Orro. 2013. Milk haptoglobin, milk amyloid A, and $N$-acetyl$\beta$-D-glucosaminidase activity in bovines with naturally occurring clinical mastitis diagnosed with a quantitative PCR test. J. Dairy Sci. 96:3662-3670.

Klingenberg, C., A. Rønnestad, A. S. Anderson, T. G. Abrahamsen, J. Zorman, A. Villaruz, T. Flægstad, M. Otto, and J. Ericson Sollid. 2007. Persistent strains of coagulase-negative staphylococci in a neonatal intensive care unit: virulence factors and invasiveness. Clin. Microbiol. Infect. 13:1100-1111.

Koop, G., A. De Visscher, C. A. Collar, D. A. Bacon, E. A. Maga, J. D. Murray, K. Supré, S. De Vliegher, F. Haesebrouck, J. D. Rowe, M. Nielen, and T. van Werven. 2012a. Short communication: Identification of coagulase-negative Staphylococcus species from goat milk with the API Staph identification test and with transfer RNA-intergenic spacer PCR combined with capillary electrophoresis. J. Dairy Sci. 95:7200-7205.

Koop, G., S. De Vliegher, A. De Visscher, K. Supré, F. Haesebrouck, M. Nielen, and T. van Werven. 2012b. Differences between coagulase-negative Staphylococcus species in persistence and in effect on somatic cell count and milk yield in dairy goats. J. Dairy Sci. 95:5075-5084.

Koop, G., T. van Werven, H. J. Schuiling, and M. Nielen. 2010. The effect of subclinical mastitis on milk yield in dairy goats. J. Dairy Sci. 93:5809-5817.

Leitner, G., U. Merin, Y. Lavi, A. Egber, and N. Silanikove. 2007. Aetiology of intramammary infection and its effect on milk composition in goat flocks. J. Dairy Res. 74:186-193.

Leitner, G., U. Merin, N. Silanikove, E. Ezra, M. Chaffer, N. Gollop, M. Winkler, A. Glickman, and A. Saran. 2004. Effect of subclinical intramammary infection on somatic cell counts, NAGase activity and gross composition of goats' milk. J. Dairy Res. 71:311-315.

Lu, T., J. Y. Park, K. Parnell, L. K. Fox, and M. A. McGuire. 2012. Characterization of fatty acid modifying enzyme activity in staphylococcal mastitis isolates and other bacteria. BMC Res. Notes 5:323

Mack, D., M. Haeder, N. Siemssen, and R. Laufs. 1996. Association of biofilm production of coagulase-negative staphylococci with expression of a specific polysaccharide intercellular adhesin. J. Infect. Dis. 174:881-884.

Matthews, K. R., R. J. Harmon, and B. E. Langlois. 1991. Effect of naturally occurring coagulase-negative staphylococci infections on new infections by mastitis pathogens in the bovine. J. Dairy Sci. 74:1855-1859.

Merino, N., A. Toledo-Arana, M. Vergara-Irigaray, J. Valle, C. Solano, E. Calvo, J. A. Lopez, T. J. Foster, J. R. Penadés, and I. Lasa. 2009. Protein A-mediated multicellular behavior in Staphylococcus aureus. J. Bacteriol. 191:832-843.

Møretrø, T., L. Hermansen, A. L. Holck, M. S. Sidhu, K. Rudi, and S. Langsrud. 2003. Biofilm formation and the presence of the intercellular adhesion locus ica, among staphylococci from food and food processing environments. Appl. Environ. Microbiol. 69:5648-5655.

Mørk, T., H. J. Jørgensen, M. Sunde, B. Kvitle, S. Sviland, S. Waage, and T. Tollersrud. 2012. Persistence of staphylococcal species and genotypes in the bovine udder. Vet. Microbiol. 159:171-180.

Moroni, P., G. Pisoni, G. Ruffo, and P. J. Boettcher. 2005. Risk factors for intramammary infections and relationship with somaticcell counts in Italian dairy goats. Prev. Vet. Med. 69:163-173.

Myllys, V. 1995. Staphylococci in heifer mastitis before and after parturition. J. Dairy Res. 62:51-60.

Nemati, M., K. Hermans, D. Vancraeynest, S. De Vliegher, O. C. Sampimon, M. Baele, E. M. De Graef, F. Pasmans, and F. Haesebrouck. 2008. Screening of bovine coagulase-negative staphylococci from milk for superantigen-encoding genes. Vet. Rec. 163:740 743

Novick, R. P. 2006. Staphylococcal pathogenesis and pathogenicity factors: Genetics and regulation. Pages 496-516 in Gram-Positive Pathogens. 2nd ed. V. A. Fischetti, R. P. Novick, J. J. Ferretti, D. A. Portnoy, and J. I. Rood, ed. ASM Press, Washington, DC.

O'Neill, E., C. Pozzi, P. Houston, H. Humphreys, D. A. Robinson, A Loughman, T. J. Foster, and J. P. O'Gara. 2008. A novel Staphylococcus aureus biofilm phenotype mediated by the fibronectin-binding proteins, FnBPA and FnBPB. J. Bacteriol. 190:3835-3850. 
Oikonomou, G., V. S. Machado, C. Santisteban, Y. H. Schukken, and R. C. Bicalho. 2012. Microbial diversity of bovine mastitic milk as described by pyrosequencing of metagenomic 16s rDNA. PLoS ONE 7:e47671.

Oliveira, M., R. Bexiga, S. F. Nunes, C. Carneiro, L. M. Cavaco, F. Bernardo, and C. L. Vilela. 2006. Biofilm-forming ability profiling of Staphylococcus aureus and Staphylococcus epidermidis mastitis isolates. Vet. Microbiol. 118:133-140.

Oliveira, M., S. F. Nunes, C. Carneiro, R. Bexiga, F. Bernardo, and C. L. Vilela. 2007. Time course of biofilm formation by Staphylococcus aureus and Staphylococcus epidermidis mastitis isolates. Vet. Microbiol. 124:187-191.

Onni, T., G. Sanna, G. P. Cubeddu, G. Marogna, S. Lollai, G. Leori, and S. Tola. 2010. Identification of coagulase-negative staphylococci isolated from ovine milk samples by PCR-RFLP of $16 \mathrm{~S}$ rRNA and gap genes. Vet. Microbiol. 144:347-352.

Onni, T., A. Vidili, E. Bandino, G. Marogna, S. Schianchi, and S. Tola. 2012. Identification of coagulase-negative staphylococci isolated from caprine milk samples by PCR-RFLP of groEL gene. Small Rumin. Res. 104:185-190.

Otto, M. 2013. Staphylococcal infections: Mechanisms of biofilm maturation and detachment as critical determinants of pathogenicity. Annu. Rev. Med. 64:175-188.

Paradis, M. E., E. Bouchard, D. T. Scholl, F. Miglior, and J. P. Roy. 2010. Effect of nonclinical Staphylococcus aureus or coagulase-negative staphylococci intramammary infection during the first month of lactation on somatic cell count and milk yield in heifers. J. Dairy Sci. 93:2989-2997.

Park, J. Y., L. K. Fox, K. S. Seo, M. A. McGuire, Y. H. Park, F. R. Rurangirwa, W. M. Sischo, and G. A. Bohach. 2011a. Comparison of phenotypic and genotypic methods for the species identification of coagulase-negative staphylococcal isolates from bovine intramammary infections. Vet. Microbiol. 147:142-148.

Park, J. Y., L. K. Fox, K. S. Seo, M. A. McGuire, Y. H. Park, F. R. Rurangirwa, W. M. Sischo, and G. A. Bohach. 2011b. Detection of classical and newly described staphylococcal superantigen genes in coagulase-negative staphylococci isolated from bovine intramammary infections. Vet. Microbiol. 147:149-154.

Pearson, L. J., J. H. Williamson, S.-A. Turner, S. J. Lacy-Hulbert, and J. E. Hillerton. 2013. Peripartum infection with Streptococcus uberis but not coagulase negative staphylococci reduced milk production in primiparous cows. J. Dairy Sci. 96:158-164.

Persson Waller, K., A. Aspán, A. Nyman, Y. Persson, and U. Grönlund Andersson. 2011. CNS species and antimicrobial resistance in clinical and subclinical bovine mastitis. Vet. Microbiol. 152:112-116.

Piepers, S., S. De Vliegher, A. de Kruif, G. Opsomer, and H. W. Barkema. 2009. Impact of intramammary infections in dairy heifers on future udder health, milk production, and culling. Vet. Microbiol. 134:113-120.

Piepers, S., G. Opsomer, H. W. Barkema, A. de Kruif, and S. De Vliegher. 2010. Heifers infected with coagulase-negative staphylococci in early lactation have fewer cases of clinical mastitis and higher milk production in their first lactation than noninfected heifers. J. Dairy Sci. 93:2014-2024.

Piepers, S., K. Peeters, G. Opsomer, H. W. Barkema, K. Frankena, and S. De Vliegher. 2011. Pathogen group specific risk factors at herd, heifer and quarter levels for intramammary infections in early lactating dairy heifers. Prev. Vet. Med. 99:91-101.

Piepers, S., Y. H. Schukken, P. Passchyn, and S. De Vliegher. 2013. The effect of intramammary infection with coagulase-negative staphylococci in early lactating heifers on milk yield throughout first lactation revisited. J. Dairy Sci. 96:5095-5105.

Piessens, V., S. De Vliegher, B. Verbist, G. Braem, A. Van Nuffel, L. De Vuyst, M. Heyndrickx, and E. Van Coillie. 2012. Characterization of coagulase-negative Staphylococcus species from cows' milk and environment based on bap,icaA, and mecA genes and phenotypic susceptibility to antimicrobials and teat dips. J. Dairy Sci. 95:7027-7038

Piessens, V., K. Supré, M. Heyndrickx, F. Haesebrouck, S. De Vliegher, and E. Van Coillie. 2010. Validation of amplified fragment length polymorphism genotyping for species identification of bo- vine associated coagulase-negative staphylococci. J. Microbiol. Methods 80:287-294.

Piessens, V., E. Van Coillie, B. Verbist, K. Supré, G. Braem, A. Van Nuffel, L. De Vuyst, M. Heyndrickx, and S. De Vliegher. 2011. Distribution of coagulase-negative Staphylococcus species from milk and environment of dairy cows differs between herds. J. Dairy Sci. 94:2933-2944.

Pyörälä, S., and S. Taponen. 2009. Coagulase-negative staphylococciEmerging mastitis pathogens. Vet. Microbiol. 134:3-8.

Quirk, T., L. K. Fox, D. D. Hancock, J. Capper, J. Wenz, and J. Park. 2012. Intramammary infections and teat canal colonization with coagulase-negative staphylococci after postmilking teat disinfection: Species-specific responses. J. Dairy Sci. 95:1906-1912.

Rainard, P., M. Ducelliez, and B. Poutrel. 1990. The contribution of mammary infections by coagulase-negative staphylococci to the herd bulk milk somatic cell count. Vet. Res. Commun. 14:193198.

Rainard, P., and B. Poutrel. 1988. Effect of naturally occurring intramammary infections by minor pathogens on new infections by major pathogens in cattle. Am. J. Vet. Res. 49:327-329.

Rajala-Schultz, P. J., A. H. Torres, F. J. DeGraves, W. A. Gebreyes, and P. Patchanee. 2009. Antimicrobial resistance and genotypic characterization of coagulase-negative staphylococci over the dry period. Vet. Microbiol. 134:55-64.

Reyher, K. K., and I. R. Dohoo. 2011. Diagnosing intramammary infections: Evaluation of composite milk samples to detect intramammary infections. J. Dairy Sci. 94:3387-3396.

Reyher, K. K., I. R. Dohoo, D. T. Scholl, and G. P. Keefe. 2012a. Evaluation of minor pathogen intramammary infection, susceptibility parameters, and somatic cell counts on the development of new intramammary infections with major mastitis pathogens. J. Dairy Sci. 95:3766-3780.

Reyher, K. K., S. Dufour, H. W. Barkema, L. Des Côteaux, T. J. Devries, I. R. Dohoo, G. G. P. Keefe, J. P. Roy, and D. T. Scholl 2011. The National Cohort of Dairy Farms - A data collection platform for mastitis research in Canada. J. Dairy Sci. 94:1616-1626.

Reyher, K. K., D. Haine, I. R. Dohoo, and C. W. Revie. 2012b. Examining the effect of intramammary infections with minor mastitis pathogens on the acquisition of new intramammary infections with major mastitis pathogens-A systematic review and meta-analysis. J. Dairy Sci. 95:6483-6502.

Rohde, H., C. Burdelski, K. Bartscht, M. Hussain, F. Buck, M. A. Horstkotte, J. K.-M. Knobloch, C. Heilmann, M. Herrmann, and D. Mack. 2005. Induction of Staphylococcus epidermidis biofilm formation via proteolytic processing of the accumulation-associated protein by staphylococcal and host proteases. Mol. Microbiol. 55:1883-1895.

Sampimon, O. C., H. W. Barkema, I. M. G. A. Berends, J. Sol, and T. J. G. M. Lam. 2009a. Prevalence and herd-level risk factors for intramammary infection with coagulase-negative staphylococci in Dutch dairy herds. Vet. Microbiol. 134:37-44.

Sampimon, O. C., R. N. Zadoks, S. De Vliegher, K. Supré, F. Haesebrouck, H. W. Barkema, J. Sol, and T. J. G. M. Lam. 2009b. Performance of API Staph ID 32 and Staph-Zym for identification of coagulase-negative staphylococci isolated from bovine milk samples. Vet. Microbiol. 136:300-305.

Sawant, A. A., B. E. Gillespie, and S. P. Oliver. 2009. Antimicrobial susceptibility of coagulase-negative Staphylococcus species isolated from bovine milk. Vet. Microbiol. 134:73-81.

Schukken, Y. H., R. N. Gonzalez, L. L. Tikofsky, H. F. Schulte, C. G. Santisteban, F. L. Welcome, G. J. Bennett, M. J. Zurakowski, and R. N. Zadoks. 2009. CNS mastitis: Nothing to worry about? Vet. Microbiol. 134:9-14.

Seo, K. S., S. U. Lee, Y. H. Park, W. C. Davis, L. K. Fox, and G. A. Bohach. 2007. Long-term staphylococcal enterotoxin C1 exposure induces soluble factor-mediated immunosuppression by bovine $\mathrm{CD}^{+}$and $\mathrm{CD} 8^{+} \mathrm{T}$ cells. Infect. Immun. 75:260-269.

Simojoki, H., P. Hyvönen, C. Plumed Ferrer, S. Taponen, and S. Pyörälä. 2012. Is the biofilm formation and slime producing ability of coagulase-negative staphylococci associated with the persis- 
tence and severity of intramammary infection? Vet. Microbiol. 158:344-352.

Simojoki, H., T. Orro, S. Taponen, and S. Pyörälä. 2009. Host response in bovine mastitis experimentally induced with Staphylococcus chromogenes. Vet. Microbiol. 134:95-99.

Simojoki, H., T. Salomäki, S. Taponen, A. Iivanainen, and S. Pyörälä. 2011. Innate immune response in experimentally induced bovine intramammary infection with Staphylococcus simulans and S. epidermidis. Vet. Res. 42:49.

Smith, E. M., L. E. Green, G. F. Medley, H. E. Bird, L. K. Fox, Y. H. Schukken, J. V. Kruze, A. J. Bradley, R. N. Zadoks, and C. G. Dowson. 2005. Multilocus sequence typing of intercontinental bovine Staphylococcus aureus isolates. J. Clin. Microbiol. 43:47374743.

Human Microbiome Project Consortium. 2012. Structure, function and diversity of the healthy human microbiome. Nature 486:207-214.

Supré, K., F. Haesebrouck, R. N. Zadoks, M. Vaneechoutte, S. Piepers, and S. De Vliegher. 2011. Some coagulase-negative Staphylococcus species affect udder health more than others. J. Dairy Sci. 94:2329-2340.

Taponen, S., J. Björkroth, and S. Pyörälä. 2008. Coagulase-negative staphylococci isolated from bovine extramammary sites and intramammary infections in a single dairy herd. J. Dairy Res. 75:422429.

Taponen, S., J. Koort, J. Björkroth, H. Saloniemi, and S. Pyörälä. 2007. Bovine intramammary infections caused by coagulase-negative staphylococci may persist throughout lactation according to amplified fragment length polymorphism-based analysis. J. Dairy Sci. 90:3301-3307.

Taponen, S., H. Simojoki, M. Haveri, H. D. Larsen, and S. Pyörälä. 2006. Clinical characteristics and persistence of bovine mastitis caused by different species of coagulase-negative staphylococci identified with API or AFLP. Vet. Microbiol. 115:199-207.

Taponen, S., K. Supré, V. Piessens, E. Van Coillie, S. De Vliegher, and J. M. Koort. 2012. Staphylococcus agnetis sp. nov., a coagulasevariable species from bovine subclinical and mild clinical mastitis. Int. J. Syst. Evol. Microbiol. 62:61-65.
Thorberg, B.-M., and B. Brändström. 2000. Evaluation of two commercial systems and a new identification scheme based on solid substrates for identifying coagulase-negative staphylococci from bovine mastitis. J. Vet. Med. B Infect. Dis. Vet. Public Health 47:683-691.

Thorberg, B.-M., M.-L. Danielsson-Tham, U. Emanuelson, and K. Persson Waller. 2009. Bovine subclinical mastitis caused by different types of coagulase-negative staphylococci. J. Dairy Sci 92:4962-4970.

Timms, L. L., and L. H. Schultz. 1987. Dynamics and significance of coagulase-negative staphylococcal intramammary infections. J. Dairy Sci. 70:2648-2657.

Tormo, M. Á., E. Knecht, F. Götz, I. Lasa, and J. R. Penadés. 2005. Bap-dependent biofilm formation by pathogenic species of Staphylococcus: Evidence of horizontal gene transfer? Microbiology 151:2465-2475.

Tremblay, Y. D., D. Lamarche, P. Chever, D. Haine, S. Messier, and M. Jacques. 2013. Characterization of the ability of coagulasenegative staphylococci isolated from the milk of Canadian farms to form biofilms. J. Dairy Sci. 96:234-246.

Ünal, N., and O. D. Çinar. 2012. Detection of staphylococcal enterotoxin, methicillin-resistant and Panton-Valentine leukocidin genes in coagulase-negative staphylococci isolated from cows and ewes with subclinical mastitis. Trop. Anim. Health Prod. 44:369-375.

Waage, S., T. Mørk, A. Røros, D. Aasland, A. Hunshamar, and S. A. Ødegaard. 1999. Bacteria associated with clinical mastitis in dairy heifers. J. Dairy Sci. 82:712-719.

Watts, J. L., A. S. Naidu, and T. Wadström. 1990. Collagen binding, elastase production, and slime production associated with coagulase-negative staphylococci isolated from bovine intramammary infections. J. Clin. Microbiol. 28:580-583.

Watts, J. L., and W. E. Owens. 1987. Synergistic hemolysis associated with coagulase-negative staphylococci isolated from bovine mammary glands. J. Clin. Microbiol. 25:2037-2039.

Zhang, S., and C. W. Maddox. 2000. Cytotoxic activity of coagulase-negative staphylococci in bovine mastitis. Infect. Immun. 68:1102-1108. 